\title{
Uji Residu Pupuk Kandang Sapi dan Jarak Tanam Sorgum (Sorghum bicolor L.) terhadap Pertumbuhan dan Hasil Tanaman Kacang Tanah (Arachis hypogeae L.) dalam Tumpangsari
}

\author{
Alfianus Haumen , \\ ${ }^{a}$ Fakultas Pertanian, Universitas Timor, Kefamenanu, TTU - NTT, Indonesia, email: alfianushaumein28@gmail.com
}

\section{Article Info}

Article history:

Received 19 Desember 2019

Received in revised form 10 Maret 2020

Accepted 14 April 2020

DOI:

https://doi.org/10.32938/sc.v5i02.930

Keywords:

Arachis Hypogeae, $\mathrm{L}$.

Jarak Tanam

Pupuk Kandang Sapi

Residu

Tumpangsari

\section{Abstrak}

Penelitian untuk mengetahui pengaruh dan interaksi uji residu pupuk kandang sapi dan jarak tanam Sorgum (Sorghum bicolor L.) dalam tumpangsari dengan Kacang Tanah (Arachis hypogeae L.) terhadap pertumbuhan dan hasil tanaman Sorgum dan Kacang Tanah. Penelitian ini dilaksanakan pada bulan Juli sampai bulan Oktober 2019 di kebun percobaan Fakultas Pertanian, Universitas Timor, Kelurahan Sasi, Kecamatan Kota Kefamenanu, Kabupaten TTU dengan menggunakan Rancangan Acak Kelompok (RAK) faktorial 4 x 3 ditambah petak monokultur Sorgum dan Kacang Tanah yakni: faktor pertama takaran residu pupuk kandang sapi: tanpa pupuk, takaran pupuk $10 \mathrm{t} / \mathrm{ha}$, takaran pupuk $20 \mathrm{t} / \mathrm{ha}$, takaran pupuk $30 \mathrm{t} / \mathrm{ha}$, faktor kedua jarak tanam: jarak tanam $20 \mathrm{~cm} \mathrm{x} 70 \mathrm{~cm}$, jarak tanam $30 \mathrm{~cm} \times$ $70 \mathrm{~cm}$, jarak tanam $40 \mathrm{~cm} \times 70 \mathrm{~cm}$. Setiap kombinasi perlakuan diulang sebanyak 3 kali sehingga terdapat 52 unit satuan penelitian. Hasil Penelitian menunjukkan bahwa tidak terjadi interaksi antara residu pupuk kandang sapi dengan jarak tanam pada semua parameter pengamatan. Perlakuan residu pupuk kandang sapi menunjukkan berbeda nyata dengan kontrol pada semua parameter pertumbuhan maupun parameter hasil dengan hasil biji kering per hektar diberikan oleh residu pupuk kandang sapi 30 t/ha. Perlakuan jarak tanam menunjukkan bahwa tidak berbeda nyata pada semua aras perlakuan kecuali pada parameter berat biji pertanaman, jarak tanam $20 \mathrm{~cm} x$ $70 \mathrm{~cm}$ menghasilkan biji kacang terberat.

\section{Pendahuluan}

Kacang tanah merupakan salah satu tanaman leguminose yang sangat berperan penting bagi kebutuhan pangan, selain itu memiliki nilai ekonomi yang tinggi sehingga banyak yang menjadikan kacang tanah selain bahan pangan juga sebagai bahan industri. Hal ini karena kandungan protein yang terdapat di dalamnya. Menurut Murrinie (2010) sebagai bahan pangan dan makanan yang bergizi tinggi, kacang tanah mengandung lemak 40-50\%, protein $27 \%$, karbohidrat dan vitamin. Kacang tanah (Arachis hypoggaea L.) adalah tanaman polong-polongan yang termasuk dalam anggota famili fabaceae. Kacang tanah mengandung lemak $45 \%$ dan protein $27 \%$, protein yang ada didalam tanaman kacang tanah jauh lebih tinggi dari pada protein yang terdapat pada daging dan telur, juga terdapat zat besi, vitamin E dan kalsium, vitamin B kompleks dan fosforus, vitamin A dan K, lesitin, kolin dan kalsium. Dimana semua zat yang terdapat didalam usaha menambahkan pertumbuhan, mencerdaskan sampai melatih ketahanan tubuh dalam mengadapi beberapa penyakit (Vyan, 2009). Umumnya lahan kering mempunyai daya dukung produktivitas terhadap tanaman yang rendah. Dalam meningkatkan produktivitas lahan kering tersebut perlu diterapkan pola tanam tumpangsari, misalnya tumpangsari tanaman sorgum dan kacang tanah. Persaingan yang terjadi antara kedua species tersebut adalah persaingan dalam memperoleh hara. Namun karena sistem perakaran tanaman sorgum lebih dalam dari pada tanaman kacang tanah, maka persaingan lebih berkurang selain akar tanaman kacang tanah dapat mampu menambat gas N2 dari udara. Selain itu, untuk mengurangi persaingan dalam memperoleh cahaya matahari maka dapat diatur jarak tanam.

Produksi tanaman dalam tumpangsari dapat menambah jenis tanaman pokok dan sisipannya jika terjadi kecocokan (Pratama, 2014). Kenyataan dalam budidaya sorgum sudah sejak lama dilakukan para petani, tetapi masih dibudidayakan secara monokultur atau tumpangsari tetapi dengan berbagai jenis tanaman lain secara tidak beraturan sehingga produksinya masih rendah. Pada tahun 2005 sampai 2011 dipandang perkembangan luas panen tanaman sorgum cenderung menurun, namun terjadi penambahan produksi dan produktivitas. Peningkatan luas panen dapat terjadi ditahun 2009 sampai 2011 dapat tercapai lebih besar dari $20 \%$ per tahun (Direktorat Budidaya Serealia, 2013). Salah satu cara untuk meningkatkan lahan menjadi efisien dengan menggunakan pola tanam tumpangsari (Lihtourgidis, et al., 2011). Namun perlu diatur pertanamannya agar tidak terjadi kompetisi ruang tumbuh dan penyerapan air serta unsur hara agar tanaman dalam tumpangsari dapat tumbuh dan berproduksi dengan baik. Misalnya tumpangsari sorgum dengan kacang tanah. Tanaman sorgum dapat ditanam secara tumpangsari dengan tanaman kacang tanah sebab tanaman kacang tanah dapat menambat nitrogen di udara, sehingga bila ditumpangsarikan dengan sorgum akan sangat efisien. Hasil penelitian Ikun (2019), dengan perlakuan pupuk kandang sapi pada takaran 30 t/ha dan jarak tanam $20 \mathrm{~cm}$ x $70 \mathrm{~cm}$ dapat meningkatkan pertumbuhan dan hasil tanaman sorgum dan kacang tanah yang ditumpangsarikan. Dari penelitian tersebut disarankan untuk dilanjutkan uji residu pupuk kandang dan jarak tanam sama.

Pupuk kandang dapat meningkatkan $\mathrm{pH}$, kadar C-organik, nitrogen, fosfor, kalium dan unsur mikro bagi tanaman (Suprijadi et al., 2002). Penggunaan bahan organik tidak hanya menambah ketersediaan hara bagi tanaman, tetapi juga menciptakan kondisi yang sesuai bagi tanaman dengan memperbaiki aerasi, mempermudah penetrasi akar, dan memperbaiki kapasitas menahan air (BOA, 2008). Penggunaan pupuk kandang di dalam tanah dapat meninggalkan residu di dalam tanah. Residu bahan organik merupakan bahan yang ditinggalkan di dalam tanah sesudah perlakuan pemberian pupuk kandang. Residu yang tersimpan di dalam tanah dari hasil kegiatan budidaya tanaman dapat dimanfaatkan lagi oleh tanaman pada penanaman berikutnya. Efek residu dari pupuk organik dapat menjadi cadangan unsur hara sehingga dapat dimanfatkan untuk penanaman pada periode berikutnya (Yulia dan Murniati, 2010). Namun hal ini belum diketahui pengaruhnya, terutama terhadap pertumbuhan dan hasil tanaman sorgum dengan kacang tanah yang ditumpangsarikan. Dalam hal ini, tentu harus diperhatikan pula jarak tanamnya.

Pengaturan jarak tanam sangat tergantung kepada tingkat kesuburan tanah dan kondisi kelembaban tanah. Mayadewi (2007) menyatakan bahwa jarak tanam sangan penting dalam menunjang kualitas dan kuantitas suatu produksi. Jarak tanam memiliki fungsi bagi tanaman untuk merendahkan tingkat persaingan suatu tanaman dengan beberapa tanaman lainnya dalam menerima sinar matahari yang optimal sehingga tidak terjadi hambatan dalam kegiatan fotosintesis oleh tanaman lain, untuk menurunkan tingkat persaingan tanaman dengan tanaman lain dalam mendapatkan unsur hara dari dalam tanah sehingga tanaman tersebut dapat menghasilkan produksi yang maksimal.

Berdasarkan uraian diatas dilakukan penelitian untuk mengetahui Pengaruh Residu Pupuk Kandang Sapi dan Jarak Tanam Sorgum (Sorghum Bicolor L.) dalam Tumpangsari dengan Kacang Tanah (Arachis Hypogeae L.) terhadap Pertumbuhan dan Hasil Kacang Tanah.

\section{Metode}

Penelitian ini dilaksanakan pada 06 Juli sampai 26 November 2019, Penelitian dilakukan di Lahan Pertanian Fakultas Pertanian, Universitas Timor, Kabupaten Timor Tengah Utara (TTU), Provinsi Nusa Tenggara Timur (NTT), pada topografi berbukit dengan ketinggian $450 \mathrm{Mdpl}$, suhu udara berkisar 32$34^{\circ} \mathrm{C}$ dan $\mathrm{pH}$ tanah berkisar $6,0-6,5$. Penelitian ini menggunakan rancangan acak kelompok (RAK) faktorial dengan $4 \times 3$ ditambah petak monokultur sorgum dan kacang tanah. Faktor pertama adalah residu pupuk kandang sapi (T) yang terdiri dari 4 aras yaitu: $\mathrm{T}_{0}=$ tanpa pupuk (kontrol), $\mathrm{T}_{1}=$ pupuk kandang sapi $5 \mathrm{t} / \mathrm{ha}, \mathrm{T}_{2}=$ pupuk kandang sapi $10 \mathrm{t} / \mathrm{ha}, \mathrm{T}_{3}=$ pupuk kandang sapi 15 t/ha. Faktor kedua adalah: jarak tanam sorgum (J) dengan 3 aras yaitu: $J_{1}=$ jarak tanam sorgum $20 \mathrm{~cm} \times 70 \mathrm{~cm}, \mathrm{~J}_{2}=$ jarak tanam sorgum $30 \mathrm{~cm} \times 70 \mathrm{~cm}, \mathrm{~J}_{3}$ $=$ jarak tanam sorgum $40 \mathrm{~cm} \times 70 \mathrm{~cm}$. Dari kedua faktor perlakuan diperoleh 12 kombinasi penelitian yaitu: $T_{0} J_{1}, T_{0} J_{2}, T_{0} J_{3}, T_{1} J_{1}, T_{1} J_{2}, T_{1} J_{3}, T_{2} J_{1}, T_{2} J_{2}, T_{2} J_{3}, T_{3} J_{1}$ $\mathrm{T}_{3} \mathrm{~J}_{2}, \mathrm{~T}_{3} \mathrm{~J}_{3}$, dan masing-masing unit diulang 3 kali ditambah petak monokultur sorgum sebanyak 12 unit dan monokutur kacang tanah sebanyak 4 unit sehingga terdapat 52 unit perlakuan kombinasi.

Parameter penelitian yang dapat digunakan dalam penelitian adalah: suhu udara, kadar lengas tanah, tinggi tanaman, jumlah daun, diameter batang, luas daun, panjang akar jumlah bintil akar total, total bintil akar efektif, berat kering berangkasan, berat kering biji per per hektar, berat biji per tanaman, berat 100 biji, berat biji per petak, indeks panen. Semua data yang dikumpulkan dalam penelitian ini diuji dengan menggunakan analisis sidik ragam anova RAK faktorial. Untuk mengetahui beda nyata diantara semua rata-rata perlakuan dalam penelitian, selanjutnya dianalisis menggunakan DMRT (Duncan Multiple Range Test) dengan tingkat signifikan $5 \%$ sesuai petunjuk Gomez dan Gomez (2010). Analisis data menggunakan program SAS 9.1.

\section{Hasil dan Pembahasan \\ 3.1 Hasil Suhu Tanah}

Hasil sidik ragam (Anova) menunjukkan bahwa tidak terjadi interaksi antara perlakuan residu pupuk kandang sapi dan jarak tanam terhadap parameter suhu tanah pada waktu pengamatan sesudah penanaman (14 HST), aras perlakuan residu pupuk kadang sapi 30 ton/ha menghasilkan suhu tanah tinggi dan tidak berbeda nyata dengan perlakuan lainnya. Pengamatan 30 HST aras perlakuan tanpa pupuk (kontrol) menghasilkan suhu paling tinggi yang tidak berbeda nyata dengan perlakuan lainnya dan pengamatan $60 \mathrm{HST}$ aras 
perlakuan residu pupuk kandang sapi $10 \mathrm{t} / \mathrm{ha}$ menghasilkan suhu paling tinggi yang tidak berbeda nyata dengan perlakuan lainnya. Pengamatan 14 HST aras perlakuan jarak tanam $20 \mathrm{~cm}$ x $70 \mathrm{~cm}$ menghasilkan suhu tanah paling rendah yang tidak berbeda nyata dengan perlakuan lainnya. Pengamatan 30 HST aras perlakuan jarak tanam $20 \mathrm{~cm} \times 70 \mathrm{~cm}$ menghasilkan suhu tanah paling tinggi yang tidak berbeda nyata dengan perlakuan lainnya dan pengamatan 60 HST aras perlakuan jarak tanam $30 \mathrm{~cm} \times 70 \mathrm{~cm}$ menghasilkan suhu tanah paling tinggi yang tidak berbeda nyata dengan perlakuan lainnya (Tabel 1).

Tabel 1. Suhu Tanah $\left({ }^{\circ} \mathrm{C}\right)$

\begin{tabular}{ccccccc}
\multirow{2}{*}{$\begin{array}{c}\text { Waktu } \\
\text { Pengamatan } \\
\text { (HST) }\end{array}$} & $\begin{array}{c}\text { Perlakuan } \\
\text { Jarak Tanam }\end{array}$ & \multicolumn{6}{l}{ Takaran Pupuk Kandang Sapi (t/ha) } & \\
\cline { 3 - 6 } & Sorgum $(\mathrm{cm})$ & 0 & 10 & 20 & 30 & \\
\hline \multirow{2}{*}{14} & $20 \times 70$ & 33,33 & 32 & 32 & 32 & $32,33 \mathrm{a}$ \\
& $30 \times 70$ & 33,67 & 34,33 & 32,33 & 32,67 & $33,25 \mathrm{a}$ \\
& $40 \times 70$ & 32,67 & 33,67 & 33,33 & 33,67 & $33,33 \mathrm{a}$ \\
\hline \multirow{3}{*}{30} & Rerata & $33,22 \mathrm{a}$ & $33,33 \mathrm{a}$ & $32,55 \mathrm{a}$ & $32,77 \mathrm{a}$ & $(-)$ \\
\hline & $20 \times 70$ & 28,33 & 29,66 & 29,66 & 29,33 & $29,25 \mathrm{a}$ \\
& $30 \times 70$ & 29,00 & 28,33 & 27,66 & 28,33 & $28,33 \mathrm{a}$ \\
& $40 \times 70$ & 30,33 & 29,00 & 28,33 & 27,33 & $28,75 \mathrm{a}$ \\
\hline \multirow{2}{*}{60} & Rerata & $29,22 \mathrm{a}$ & $29 \mathrm{a}$ & $28,55 \mathrm{a}$ & $28,33 \mathrm{a}$ & $(-)$ \\
\hline & $20 \times 70$ & 29,00 & 28,00 & 29,00 & 28,00 & $28,50 \mathrm{a}$ \\
& $30 \times 70$ & 30,33 & 30,00 & 28,66 & 28,66 & $29,41 \mathrm{a}$ \\
& $40 \times 70$ & 30,00 & 28,66 & 29,00 & 26,33 & $28,50 \mathrm{a}$ \\
\hline
\end{tabular}

Keterangan: Angka pada baris dan kolom yang diikuti oleh huruf yang sama menunjukkan tidak berbeda nyata pada uji lanjut DMRT $\alpha$ 0,05., (-): Tidak terjadi interaksi antara perlakuan.

\section{Kadar Lengas Tanah}

Hasil sidik ragam (Anova) menunjukkan bahwa tidak terjadi interaksi antara perlakuan residu pupuk kandang sapi dan jarak tanam terhadap parameter kadar lengas tanah pada pengamatan sesudah penanaman. Aras perlakuan residu pupuk kadang sapi 30 t/ha dan jarak menghasilkan kadar lengas tanah yang paling tinggi yang tidak berbeda nyata dengan perlakuan lainnya. Jarak tanam $20 \mathrm{~cm}$ x $70 \mathrm{~cm}$ menunjukkan data tidak berbeda nyata antara perlakuan lainnya (Tabel 2).

Tabel 2. Kadar Lengas Tanah (\%)

\begin{tabular}{ccccccc}
\hline $\begin{array}{c}\text { Waktu } \\
\text { Pengamatan } \\
(\text { HST) }\end{array}$ & Perlakuan & \multicolumn{4}{c}{ Takaran Pupuk Kandang Sapi (t/ha) } & \multirow{2}{*}{ Rerata } \\
\cline { 2 - 5 } & $\begin{array}{c}\text { Jarak Tanam } \\
\text { Sorgum }(\mathrm{cm})\end{array}$ & 0 & 10 & 20 & 30 & \\
\hline \multirow{3}{*}{14} & $20 \times 70$ & 21,56 & 20,67 & 19,50 & 22,43 & $21,04 \mathrm{a}$ \\
& $30 \times 70$ & 22,57 & 18,68 & 19,75 & 22,29 & $20,82 \mathrm{a}$ \\
& $40 \times 70$ & 19,28 & 20,52 & 20,25 & 21,27 & $20,33 \mathrm{a}$ \\
\hline & Rerata & 21,13 a & 19,95 a & 19,83 a & $22,00 \mathrm{a}$ & $(-)$
\end{tabular}

Keterangan: Angka pada baris dan kolom yang diikuti oleh huruf yang sama menunjukkan tidak berbeda nyata pada uji lanjut DMRT $\alpha$ 0,05., (-): Tidak terjadi interaksi antara perlakuan.

\section{Tinggi Tanaman Kacang Tanah}

Hasil sidik ragam (Anova) menunjukkan bahwa tidak terjadi interaksi antara perlakuan residu pupuk kandang sapi dan jarak tanam terhadap parameter tinggi tanaman kacang tanah. Pada pengamatan 30 HST maupun 60 HST, aras perlakuan residu pupuk kadang sapi $30 \mathrm{t} / \mathrm{ha}$ menghasilkan tinggi tanaman paling tinggi yang berbeda nyata dengan perlakuan lainnya. Pengamatan 30 HST perlakuan jarak tanam $40 \mathrm{~cm}$ x $70 \mathrm{~cm}$ menunjukkan data tidak berbeda nyata antara perlakuan lainnya Sedangkan pengamatan $60 \mathrm{HST}$, aras perlakuan jarak tanam $20 \mathrm{~cm}$ x $70 \mathrm{~cm}$ menunjukkan tidak berbeda nyata dengan perlakuan lainnya (Tabel 3).

Tabel 3. Tinggi Tanaman Kacang Tanah $(\mathrm{cm})$

\begin{tabular}{ccccccc}
\hline $\begin{array}{c}\text { Waktu } \\
\text { Pengamatan } \\
\text { (HST) }\end{array}$ & Perlakuan & \multicolumn{4}{c}{ Takaran Pupuk Kandang Sapi (t/ha) } & \\
\cline { 2 - 6 } & $\begin{array}{c}\text { Jarak Tanam } \\
\text { Sorgum (cm) }\end{array}$ & 0 & 10 & 20 & 30 & Rerata \\
\hline \multirow{3}{*}{30} & $20 \times 70$ & 6,35 & 7,57 & 6,68 & 8,11 & $7,17 \mathrm{a}$ \\
& $30 \times 70$ & 7,09 & 5,99 & 6,75 & 8,14 & $6,99 \mathrm{a}$ \\
& $40 \times 70$ & 8,11 & 7,70 & 7,09 & 9,74 & $8,15 \mathrm{a}$ \\
\hline \multirow{2}{*}{60} & Rerata & $7,18 \mathrm{~b}$ & $7,08 \mathrm{~b}$ & $6,83 \mathrm{~b}$ & $8,66 \mathrm{a}$ & $(-)$ \\
\hline & $20 \times 70$ & 22,70 & 25,52 & 26,57 & 30,34 & $26,28 \mathrm{a}$ \\
& $30 \times 70$ & 20,87 & 23,08 & 23,94 & 28,07 & $23,98 \mathrm{a}$ \\
& $40 \times 70$ & 23,08 & 22,98 & 24,01 & 29,01 & $24,76 \mathrm{a}$ \\
\hline & Rerata & $22,21 \mathrm{~b}$ & $23,85 \mathrm{~b}$ & $24,84 \mathrm{~b}$ & $29,14 \mathrm{a}$ & $(-)$
\end{tabular}

Keterangan: Angka yang diikuti oleh huruf yang sama menunjukkan tidak berbeda nyata pada uji lanjut DMRT $\alpha$ 0,05., (-): Tidak terjadi interaksi antara perlakuan.

\section{Jumlah Tangkai Daun Kacang Tanah}

Hasil sidik ragam (Anova) menunjukkan bahwa tidak terjadi interaksi antara perlakuan residu pupuk kandang sapi dan jarak tanam terhadap parameter jumlah tangkai daun tanaman kacang tanah. Pada pengamatan 30 HST aras perlakuan residu pupuk kadang sapi $30 \mathrm{t} / \mathrm{ha}$ menghasilkan jumlah tangkai daun paling banyak yang tidak berbeda nyata dengan perlakuan tanpa pupuk (kontrol) namun berbeda nyata dengan perlakuan perlakuan lainnya.
Sedangkan pada pengamatan 60 HST aras perlakuan residu pupuk kadang sapi 30 t/ha menghasilkan jumlah tangkai daun paling banyak yang tidak berbeda nyata dengan perlakuan lainnya namun berbeda nyata dengan tanpa pupuk (kontrol). Pengamatan 30 HST Aras perlakuan jarak tanam $20 \mathrm{~cm} \times 70 \mathrm{~cm}$ menghasilkan jumlah tangkai daun paling banyak tidak berbeda nyata antara perlakuan lainnya dan pengamatan 60 HST Aras perlakuan jarak $40 \mathrm{~cm}$ x 70 $\mathrm{cm}$ menghasilkan jumlah tangkai daun paling banyak tidak berbeda nyata perlakuan lainnya (Tabel 4).

Tabel 4. Jumlah Tangkai Tanaman Kacang Tanah (Helai)

\begin{tabular}{ccccccc}
\hline $\begin{array}{c}\text { Waktu } \\
\text { Pengamatan } \\
\text { (HST) }\end{array}$ & \multicolumn{2}{c}{ Perlakuan } & \multicolumn{5}{c}{ Takaran Pupuk Kandang Sapi (t/ha) } & Rerata \\
\cline { 2 - 6 } & $\begin{array}{c}\text { Jarak Tanam } \\
\text { Sorgum }(\mathrm{cm})\end{array}$ & 0 & 10 & 20 & 30 & \\
\hline \multirow{3}{*}{30} & $20 \times 70$ & 6,34 & 7,39 & 7,06 & 7,56 & $7,08 \mathrm{a}$ \\
& $30 \times 70$ & 7,56 & 6,67 & 6,50 & 7,44 & $7,04 \mathrm{a}$ \\
& $40 \times 70$ & 7,28 & 6,67 & 6,72 & 7,50 & $7,04 \mathrm{a}$ \\
\hline \multirow{2}{*}{60} & Rerata & $7,05 \mathrm{a}$ & $6,90 \mathrm{~b}$ & $6,76 \mathrm{~b}$ & $7,49 \mathrm{a}$ & $(-)$ \\
\hline & $20 \times 70$ & 10,33 & 10,56 & 10,39 & 10,72 & $10,50 \mathrm{a}$ \\
& $30 \times 70$ & 10,11 & 10,11 & 10,50 & 10,83 & $10,38 \mathrm{a}$ \\
\hline & $40 \times 70$ & 10,33 & 10,28 & 10,39 & 11,33 & $10,58 \mathrm{a}$ \\
\hline & Rerata & $10,25 \mathrm{~b}$ & $10,31 \mathrm{a}$ & $10,42 \mathrm{a} 10,96 \mathrm{a}$ & $(-)$ \\
\hline
\end{tabular}

Keterangan: Angka yang diikuti oleh huruf yang sama menunjukkan tidak berbeda nyata pada uji lanjut DMRT $\alpha$ 0,05., (-): Tidak terjadi interaksi antara perlakuan.

\section{Diameter Batang Kacang Tanah}

Hasil sidik ragam (Anova) menunjukkan bahwa tidak terjadi interaksi antara perlakuan residu pupuk kandang sapi dan jarak tanam terhadap parameter diameter batang tanaman kacang tanah. Pada pengamatan $60 \mathrm{HST}$, aras perlakuan residu pupuk kadang sapi 30 t/ha menghasilkan diameter batang yang paling besar yang berbeda nyata dengan perlakuan lainnya. Aras perlakuan jarak tanam $40 \mathrm{~cm}$ x $70 \mathrm{~cm}$ menghasilkan diameter batang paling besar yang menunjukkan data tidak berbeda nyata antara perlakuan lainnya (Tabel 5).

Tabel 5. Diameter Batang Tanaman Kacang Tanah (cm)

\begin{tabular}{|c|c|c|c|c|c|c|}
\hline \multirow{2}{*}{$\begin{array}{c}\text { Waktu } \\
\text { Pengamatan } \\
\text { (HST) }\end{array}$} & \multirow{2}{*}{$\begin{array}{c}\text { Perlakuan } \\
\text { Jarak Tanam } \\
\text { Sorgum }(\mathrm{cm})\end{array}$} & \multicolumn{4}{|c|}{ Takaran Pupuk Kandang Sapi (t/ha) } & \multirow[b]{2}{*}{ Rerata } \\
\hline & & 0 & 10 & 20 & 30 & \\
\hline \multirow{4}{*}{60} & $20 \times 70$ & 0,50 & 0,51 & 0,50 & 0,52 & $0,50 \mathrm{a}$ \\
\hline & $30 \times 70$ & 0,49 & 0,52 & 0,51 & 0,55 & $0,51 \mathrm{a}$ \\
\hline & $40 \times 70$ & 0,48 & 0,51 & 0,54 & 0,58 & $0,52 \mathrm{a}$ \\
\hline & Rerata & $0,49 \mathrm{~b}$ & $0,51 \mathrm{~b}$ & $0,51 \mathrm{~b}$ & $0,55 \mathrm{a}$ & $(-)$ \\
\hline
\end{tabular}

Keterangan: Angka yang diikuti oleh huruf yang sama menunjukkan tidak berbeda nyata pada uji lanjut DMRT $\alpha$ 0,05., (-) tidak terjadi interaksi antar perlakuan.

\section{Jumlah Total Bintil Akar Efektif Kacang Tanah}

Hasil sidik ragam (Anova) menunjukkan bahwa tidak terjadi interaksi antara perlakuan residu pupuk kandang sapi dan jarak tanam terhadap parameter jumlah total bintil akar efektif tanaman kacang tanah. Aras perlakuan residu pupuk kadang sapi 20 t/ha menghasilkan jumlah total bintil efektif yang paling banyak yang tidak berbeda nyata dengan perlakuan lainnya namun berbeda nyata dengan perlakuan residu pupuk kandang sapi 30 t/ha. Aras perlakuan jarak tanam $20 \mathrm{~cm}$ x $70 \mathrm{~cm}$ menghasilkan jumlah total bintil akar efektif paling banyak yang tidak berbeda nyata dengan perlakuan lainnya (Tabel 6).

\section{Tabel 6. Jumlah Total Bintil Akar Efektif}

\begin{tabular}{ccccccc}
\hline $\begin{array}{c}\text { Waktu } \\
\text { Pengamatan } \\
(\text { HST })\end{array}$ & Perlakuan & \multicolumn{4}{c}{ Takaran Pupuk Kandang Sapi (t/ha) } & \multirow{2}{*}{ Rerata } \\
\cline { 2 - 6 } & Jarak Tanam & 0 & 10 & 20 & 30 & \\
\hline \multirow{2}{*}{30} & Sorgum $(\mathrm{cm})$ & & & & & \\
& $20 \times 70$ & 10,66 & 15,33 & 22,66 & 12,33 & $15,25 \mathrm{a}$ \\
& $30 \times 70$ & 15,16 & 11,83 & 15,66 & 11,16 & $13,45 \mathrm{a}$ \\
& $40 \times 70$ & 15,50 & 15,66 & 14,16 & 8,16 & $13,37 \mathrm{a}$ \\
\hline \multicolumn{6}{c}{ Keterangan: Angka yang diikuti oleh huruf yang sama menunjukkan tidak berbeda nyata }
\end{tabular}
pada uji lanjut DMRT $\alpha$ 0,05., (-): Tidak terjadi interaksi antara perlakuan.

\section{Berat Kering Berangkasan Kacang Tanah}

Hasil sidik ragam (Anova) menunjukkan bahwa tidak terjadi interaksi antara perlakuan residu pupuk kandang sapi dan jarak tanam terhadap parameter berat kering berangkasan tanaman kacang tanah. Aras perlakuan residu pupuk kadang sapi 30 t/ha menghasilkan berat kering berangkasan paling berat yang berbeda tidak nyata dengan perlakuan residu pupuk kandang sapi 20 t/ha namun berbeda nyata dengan perlakuan lainnya. Aras perlakuan jarak tanam $40 \mathrm{~cm}$ x $70 \mathrm{~cm}$ menghasilkan berat berangkasan paling berat yang tidak berbeda nyata dengan perlakuan lainnya (Tabel 7).

\section{Luas Daun Kacang Tanah}

Hasil sidik ragam (Anova) menunjukkan bahwa tidak terjadi interaksi antara perlakuan residu pupuk kandang sapi dan jarak tanam terhadap parameter luas daun tanaman kacang tanah. Aras perlakuan residu pupuk kadang sapi $30 \mathrm{t} / \mathrm{ha}$ menghasilkan luas daun paling lebar yang tidak berbeda nyata dengan perlakuan residu pupuk kandang sapi 20 t/ha namun berbeda 
nyata dengan perlakuan lainnya. Aras perlakuan jarak tanam $40 \mathrm{~cm} \times 70 \mathrm{~cm}$ mengasilkan luas daun paling luas yang tidak berbeda nyata dengan perlakuan lainnya (Tabel 8).

\section{$\underline{\text { Tabel 7. Berat Kering Berangkasan (g) }}$}

\begin{tabular}{|c|c|c|c|c|c|c|}
\hline \multirow{2}{*}{$\begin{array}{c}\text { Waktu } \\
\text { Pengamatan } \\
\text { (HST) }\end{array}$} & \multirow{2}{*}{$\begin{array}{c}\text { Perlakuan } \\
\text { Jarak Tanam } \\
\text { Sorgum }(\mathrm{cm})\end{array}$} & \multicolumn{4}{|c|}{$\begin{array}{c}\text { Takaran Pupuk Kandang Sapi } \\
\text { (t/ha) }\end{array}$} & \multirow{2}{*}{ Rerata } \\
\hline & & 0 & 10 & 20 & 30 & \\
\hline \multirow{4}{*}{30} & $20 \times 70$ & 4,85 & 6,65 & 5,85 & 9,31 & $6.66 \mathrm{a}$ \\
\hline & $30 \times 70$ & 6,20 & 5,56 & 8,20 & 8,73 & $7,17 \mathrm{a}$ \\
\hline & $40 \times 70$ & 6,00 & 7,20 & 7,85 & 9,73 & $7,69 \mathrm{a}$ \\
\hline & Rerata & $5,68 \mathrm{~b}$ & $6,47 \mathrm{~b}$ & $7,30 \mathrm{a}$ & $9,26 \mathrm{a}$ & $(-)$ \\
\hline
\end{tabular}

Keterangan: Angka yang diikuti oleh huruf yang sama menunjukkan tidak berbeda nyata pada uji lanjut DMRT a 0,05., (-): Tidak terjadi interaksi antara perlakuan.

Tabel 8. Luas Daun $\left(\mathrm{cm}^{2}\right)$

\begin{tabular}{ccccccc}
\hline $\begin{array}{c}\text { Waktu } \\
\text { Pengamatan } \\
\text { (HST) }\end{array}$ & $\begin{array}{c}\text { Jarak Tanam } \\
\text { sorgum (cm) }\end{array}$ & 0 & 10 & 20 & 30 & Rerata \\
\hline \multirow{3}{*}{30} & $20 \times 70$ & 355,6 & 446,4 & 356,1 & 838,2 & $499,1 \mathrm{a}$ \\
& $30 \times 70$ & 410,1 & 275,0 & 555,6 & 610,4 & $462,7 \mathrm{a}$ \\
& $40 \times 70$ & 440,6 & 561,2 & 617,2 & 806,0 & $606,2 \mathrm{a}$ \\
\hline & Rerata & $402,1 \mathrm{~b}$ & $427,5 \mathrm{~b}$ & $509,6 \mathrm{a}$ & $751,5 \mathrm{a}$ & $(-)$ \\
\hline
\end{tabular}

Keterangan: Angka yang diikuti oleh huruf yang sama menunjukkan tidak berbeda nyata pada uji lanjut DMRT $\alpha$ 0,05., (-): Tidak terjadi interaksi antara perlakuan.

\section{Berat Biji Per Tanaman Kacang Tanah}

Hasil sidik ragam (Anova) menunjukkan bahwa tidak terjadi interaksi antara perlakuan residu pupuk kandang sapi dan jarak tanam terhadap parameter jumlah biji per tanaman kacang tanah. Aras perlakuan residu pupuk kadang sapi $30 \mathrm{t} / \mathrm{ha}$ menghasilkan berat biji pertanaman paling berat yang tidak berbeda nyata dengan perlakuan lainnya namun berbeda nyata dengan pelakuan tanpa pupuk (kontrol). Aras perlakuan jarak tanam $40 \mathrm{~cm}$ x $70 \mathrm{~cm}$ mengasilkan berat biji per tanaman paling banyak yang menunjukkan tidak berbeda nyata dengan perlakuan jarak tanam $30 \mathrm{~cm}$ x $70 \mathrm{~cm}$ dan berbeda nyata dengan perlakuan lainnya (Tabel 9).

Tabel 9. Berat Biji Per Tanaman (g)

\begin{tabular}{|c|c|c|c|c|c|c|}
\hline \multirow{2}{*}{$\begin{array}{c}\text { Waktu } \\
\text { Pengamatan } \\
\text { (HST) }\end{array}$} & \multirow{2}{*}{$\begin{array}{c}\text { Perlakuan } \\
\text { Jarak Tanam } \\
\text { Sorgum }(\mathrm{cm})\end{array}$} & \multicolumn{4}{|c|}{ Takaran Pupuk Kandang Sapi (t/ha) } & \multirow[b]{2}{*}{ Rerata } \\
\hline & & 0 & 10 & 20 & 30 & \\
\hline \multirow{4}{*}{ Panen } & $20 \times 70$ & 7,32 & 12,47 & 11,05 & 11,48 & $10,58 \mathrm{~b}$ \\
\hline & $30 \times 70$ & 9,58 & 10,50 & 12,62 & 13,83 & $11,63 \mathrm{a}$ \\
\hline & $40 \times 70$ & 9,60 & 12,81 & 12,64 & 18,40 & $13,36 \mathrm{a}$ \\
\hline & Rerata & $8,83 \mathrm{~b}$ & $11,93 \mathrm{a}$ & $12,10 \mathrm{a}$ & $14,57 \mathrm{a}$ & $(-)$ \\
\hline
\end{tabular}

Keterangan: Angka yang diikuti oleh huruf yang sama menunjukkan tidak berbeda nyata pada uji lanjut DMRT $\alpha$ 0,05., (-): Tidak terjadi interaksi antara perlakuan.

\section{Berat Biji Per Petak Kacang Tanah}

Hasil sidik ragam (Anova) menunjukkan bahwa tidak terjadi interaksi antara perlakuan residu pupuk kandang sapi dan jarak tanam terhadap parameter berat biji per petak tanaman kacang tanah. Aras perlakuan residu pupuk kadang sapi 30 t/ha menghasilkan berat biji per petak paling berat yang tidak berbeda nyata dengan perlakuan lainnya namun berbeda nyata dengan perlakuan tanpa pupuk (kontrol). Aras perlakuan jarak tanam $20 \mathrm{~cm}$ x $70 \mathrm{~cm}$ menghasilkan berat biji per petak paling tinggi yang menunjukkan data tidak berbeda nyata dengan perlakuan lainnya (Tabel 10).

Tabel 10. Berat Biji Per Petak (g)

\begin{tabular}{|c|c|c|c|c|c|c|}
\hline \multirow{2}{*}{$\begin{array}{c}\text { Waktu } \\
\text { Pengamatan } \\
\text { (HST) }\end{array}$} & \multirow{2}{*}{$\begin{array}{l}\text { Perlakuan } \\
\text { Jarak Tanam } \\
\text { Sorgum }(\mathrm{cm})\end{array}$} & \multicolumn{4}{|c|}{ Takaran Pupuk Kandang Sapi (t/ha) } & \multirow[b]{2}{*}{ Rerata } \\
\hline & & 0 & 10 & 20 & 30 & \\
\hline \multirow{4}{*}{ Panen } & $20 \times 70$ & 304,37 & 398,23 & 376,33 & 432,40 & $377.83 \mathrm{a}$ \\
\hline & $30 \times 70$ & 289,27 & 326,07 & 429,60 & 456,83 & $375.44 \mathrm{a}$ \\
\hline & $40 \times 70$ & 264,73 & 346,57 & 312,30 & 437,67 & $340.32 \mathrm{a}$ \\
\hline & Rerata & $286,12 \mathrm{~b}$ & $356,96 \mathrm{a}$ & $372,74 \mathrm{a}$ & $442,30 \mathrm{a}$ & $(-)$ \\
\hline
\end{tabular}

Keterangan: Angka yang diikuti oleh huruf yang sama menunjukkan tidak berbeda nyata pada uji lanjut DMRT $\alpha$ 0,05., (-): Tidak terjadi interaksi antara perlakuan.

\section{Berat Kering Biji Per Hektar Kacang Tanah}

Hasil sidik ragam (Anova) menunjukkan bahwa tidak terjadi interaksi antara perlakuan residu pupuk kandang sapi dan jarak tanam terhadap parameter berat kering biji per hektar tanaman kacang tanah. Aras perlakuan residu pupuk kadang sapi 30 t/ha menghasilkan berat kering biji per hektar paling berat yang tidak berbeda nyata dengan perlakuan lainnya namun berbeda nyata dengan perlakuan tanpa pupuk (kontrol). Aras perlakuan jarak tanam 20 $\mathrm{cm} \times 70 \mathrm{~cm}$ maupun $30 \mathrm{~cm}$ x $70 \mathrm{~cm}$ menghasilkan berat kering biji per hektar paling berat yang tidak berbeda nyata dengan perlakuan lainnya (Tabel 11).
Tabel 11. Berat kering biji per hektar ( $\mathrm{t} / \mathrm{ha})$

\begin{tabular}{ccccccc}
\hline \multirow{2}{*}{$\begin{array}{c}\text { Waktu } \\
\text { Pengamatan } \\
\text { (HST) }\end{array}$} & Perlakuan & \multicolumn{4}{c}{ Takaran Pupuk Kandang Sapi (t/ha) } & \multirow{2}{*}{ Rerata } \\
\cline { 2 - 6 } & $\begin{array}{c}\text { Jarak Tanam } \\
\text { Sorgum }(\mathrm{cm})\end{array}$ & 0 & 10 & 20 & 30 & \\
\hline \multirow{3}{*}{ Panen } & $20 \times 70$ & 0,60 & 0,79 & 0,74 & 0,85 & $0,74 \mathrm{a}$ \\
& $30 \times 70$ & 0,57 & 0,64 & 0,85 & 0,90 & $0,74 \mathrm{a}$ \\
& $40 \times 70$ & 0,52 & 0,68 & 0,61 & 0,86 & $0,67 \mathrm{a}$ \\
\hline & Rerata & $0,56 \mathrm{~b}$ & $0,70 \mathrm{a}$ & $0,73 \mathrm{a}$ & $0,87 \mathrm{a}$ & $(-)$ \\
\hline
\end{tabular}

Keterangan: Angka yang diikuti oleh huruf yang sama menunjukkan tidak berbeda nyata pada uji lanjut DMRT a 0,05., (-): Tidak terjadi interaksi antara perlakuan.

\section{Berat 100 Biji Kacang Tanah}

Hasil sidik ragam (Anova) menunjukkan bahwa tidak terjadi interaksi antara perlakuan residu pupuk kandang sapi dan jarak tanam terhadap parameter berat 100 biji tanaman kacang tanah. Aras perlakuan residu pupuk kadang sapi 20 t/ha menghasilkan berat 100 biji paling berat yang tidak berbeda nyata dengan perlakuan lainnya. Aras perlakuan jarak tanam $30 \mathrm{~cm}$ x $70 \mathrm{~cm}$ menghasilkan berat 100 biji paling berat yang tidak berbeda nyata dengan perlakuan lainnya (Tabel 12).

Tabel 12. Berat 100 Biji (g)

\begin{tabular}{|c|c|c|c|c|c|c|}
\hline \multirow{2}{*}{$\begin{array}{c}\text { Waktu } \\
\text { Pengamatan } \\
\text { (HST) }\end{array}$} & \multirow{2}{*}{$\begin{array}{c}\text { Perlakuan } \\
\text { Jarak Tanam } \\
\text { sorgum }(\mathrm{cm})\end{array}$} & \multicolumn{4}{|c|}{ Takaran Pupuk Kandang Sapi (t/ha) } & \multirow[b]{2}{*}{ Rerata } \\
\hline & & 0 & 10 & 20 & 30 & \\
\hline \multirow{4}{*}{ Panen } & $20 \times 70$ & 59,76 & 64,00 & 63,56 & 62,80 & $62,53 \mathrm{a}$ \\
\hline & $30 \times 70$ & 63,90 & 63,53 & 64,30 & 62,76 & $63,62 \mathrm{a}$ \\
\hline & $40 \times 70$ & 60,86 & 62,33 & 63,13 & 63,46 & $62,45 \mathrm{a}$ \\
\hline & Rerata & $61,51 \mathrm{a}$ & $63,28 \mathrm{a}$ & $63,66 \mathrm{a}$ & $63,01 \mathrm{a}$ & $(-)$ \\
\hline
\end{tabular}

pada uji lanjut DMRT a 0,05., (-): Tidak terjadi interaksi antara perlakuan.

\section{Indeks Panen Kacang Tanah}

Hasil sidik ragam (Anova) menunjukkan bahwa tidak terjadi interaksi antara perlakuan residu pupuk kandang sapi dan jarak tanam terhadap parameter indeks panen tanaman kacang tanah. Aras perlakuan residu pupuk kadang sapi $10 \mathrm{t} / \mathrm{ha}$ menghasilkan indeks panen paling baik yang tidak berbeda nyata dengan perlakuan lainnya. Aras perlakuan jarak tanam $40 \mathrm{~cm}$ x $70 \mathrm{~cm}$ menghasilkan indeks panen paling baik yang menunjukkan data tidak berbeda nyata antara perlakuan lainnya (Tabel 13).

Tabel 13. Indeks Panen (\%)

\begin{tabular}{|c|c|c|c|c|c|c|}
\hline \multirow{2}{*}{$\begin{array}{c}\text { Waktu } \\
\text { Pengamatan } \\
\text { (HST) }\end{array}$} & \multirow{2}{*}{$\begin{array}{c}\text { Perlakuan } \\
\text { Jarak Tanam } \\
\text { sorgum }(\mathrm{cm})\end{array}$} & \multicolumn{4}{|c|}{ Takaran Pupuk Kandang Sapi (t/ha) } & \multirow[b]{2}{*}{ Rerata } \\
\hline & & 0 (T0) & $\begin{array}{c}10 \\
\text { (T1) }\end{array}$ & $20(\mathrm{~T} 2)$ & $30(\mathrm{~T} 3)$ & \\
\hline \multirow{4}{*}{ Panen } & $20 \times 70(\mathrm{~J} 1)$ & 60,72 & 65,07 & 65,15 & 55,47 & $61,60 \mathrm{a}$ \\
\hline & $30 \times 70(\mathrm{~J} 2)$ & 60,14 & 65,12 & 60,72 & 61,88 & $61,96 \mathrm{a}$ \\
\hline & $40 \times 70(\mathrm{~J} 3)$ & 60,92 & 64,68 & 63,58 & 65,15 & $63,58 \mathrm{a}$ \\
\hline & Rerata & $60,59 \mathrm{a}$ & $64,96 \mathrm{a}$ & $63,15 \mathrm{a}$ & $60,83 \mathrm{a}$ & $(-)$ \\
\hline
\end{tabular}
pada uji lanjut DMRT $\alpha 0,05$., (-): Tidak terjadi interaksi antara perlakuan.

\subsection{Pembahasan}

Hasil penelitian menunjukkan bahwa residu pupuk kandang sapi dan jarak tanam dalam tumpangsari yang sudah terdapat didalam tanah menunjukkan pengaruh yang berbeda-beda terhadap pertumbuhan dan hasil tanaman Kacang Tanah yang ditanam pada periode kedua pada lahan yang sama. Peningkatan produksi tertinggi diperlihatkan dari perlakuan residu pupuk kandang sapi, dimana secara umum pertumbuhan dan hasilnya relatif lebih baik. Menurut Yulia et al. (2011), residu bahan organik dapat meningkatkan produksi sawi hijau pada musim tanam kedua. Berdasarkan pengamatan hasil penelitian menunjukan bahwa tidak terjadi interaksi antara perlakuan residu pupuk kandang sapi dan jarak tanam terhadap parameter lingkungan (suhu dan kadar lengas tanah) yang di amati.

Hal ini kemungkinan disebabkan residu pupuk kandang sapi yang terdapat di dalam tanah masih mampu menyediakan hara, terbukti bahwa suhu dapat menurun dan dibanding dengan tanah pada petak-petak yang tidak mengandung residu pupuk kandang sapi. Selain itu residu dapat meningkatkan kelengasan tanah, yang berarti bahwa residu pupuk kandang mampu memperbaiki beberapa sifat fisik. Subowo (2010) menyatakan bila semakin tinggi jumlah bahan organik dalam tanah, maka membutuhkan waktu yang lama dalam proses dekomposisi oleh mikroorganisme tanah sehingga masih meninggalkan residu bahan organik untuk penanaman selanjutnya. Menurut Adiku et al., (2008), penambahan residu akan meningkatkan karbon organik tanah. Kondisi ini mampu menahan air tanah, sehingga aktivitas mikroba tanah juga meningkat akibat adanya mineralisasi karbon.

Berbagai dosis residu pupuk kandang sapi memperlihatkan rerata pertumbuhan tanaman baik $30 \mathrm{hst}$ dan $60 \mathrm{hst}$ pada perlakuan $30 \mathrm{t} / \mathrm{ha}$, memberikan efek parameter pertumbuhan yang lebih besar dikarenakan tanah yang mengandung residu pupuk kandang sapi lebih banyak mampu menangkap air dan unsur hara yang terdapat dalam tanah dibandingkan tanaman yang tidak mengandung residu pupuk kandang sapi (kontrol). Penelitian ini menunjukkan bahwa semakin banyak pupuk kandang sapi yang diaplikasikan ke dalam tanah 
akan meninggalkan residu yang lebih banyak dikarenakan pupuk kandang sapi membutuhkan proses penguraian lebih lama dan pada akhirnya dapat dimanfaatkan untuk pertumbuhan tanaman pada penanaman kedua yang menghasilkan bobot biji yang tinggi. Ini sesuai dengan pernyataan Hakim et al., (1986) bahwa pupuk organik memiliki efek residu dimana haranya secara berangsur bebas dan tersedia bagi tanaman. Efek residu dari pupuk organik dapat menjadi cadangan hara sehingga dapat dimanfatkan untuk penanaman periode selanjutnya.

Sependapat dengan Hardjowigeno (1987),Novizan (2007), mengatakan bahwa unsur yang paling berperan dalam peningkatan tinggi tanaman dan pertumbuhan vegetatif lain seperti berat segar brangkasan dan berat kering berangkasan tanaman, adalah $\mathrm{N}$. Peran unsur $\mathrm{N}$ dalam pertumbuhan tanaman dibutuhkan untuk mendorong pertumbuhan organ - organ seperti daun yang berkaitan erat dengan fotosintesis (Permadi, 2005). Baherta (2002), pupuk kandang berfungsi untuk meningkatkan tekstur tanah, agregat tanah, daya pegang air, kapasitas tukar kation, dan meningkatkan unsur hara bagi tanaman.

Hara yang tersedia dapat menunjang pertumbuhan tanaman kacang tanah baik pada parameter pertumbuhan, dimana tanaman lebih tinggi, jumlah daun lebih banyak dan diameter batang lebih besar. Pengamatan parameter berangkasan tanaman menunjukkan bahwa residu pupuk kandang sapi 30 t/ha mampu meningkatkan pertumbuhan. Hal ini menunjukkan bahwa residu pupuk kandang yang tersedia di dalam tanah mampu memperbaiki porositas tanah sehingga akar tanaman tumbuh lebih luas dalam menyerap nutrisi yang terdapat didalam tanah. Menurut Sarief (1985) berat isi tanah dipengaruhi banyak faktor, di antaranya bahan organik tanah. Peningkatan bahan organik tanah menurunkan berat isi tanah, sehingga total ruang pori tanah meningkat atau kepadatan tanah menurun. Keadaan tersebut dapat menyebabkan pertumbuhan dan perkembangan akar menjadi lebih baik.

Hasil penelitian menunjukkan bahwa residu pupuk kandang sapi 30 t/ha yang masih ada di dalam tanah secara umum merupakan perlakuan terbaik yang terlihat di beberapa parameter dibandingkan perlakuan lainnya, seperti tanaman memiliki permukaan daun yang lebih lebar, daun kering yang lebih berat dan berangkasan kering paling berat. Menurut Mohammad et al. (2012), penggunaan residu tanaman yang dikombinasikan dengan rotasi tanaman legum dapat meningkatkan produksi biji dan berangkasan gandum jika dibandingkan dengan rotasi tanaman non legum. Menurut Blair et al. (2006), penerapan rotasi tanaman di Australia dengan memasukkan tanaman legum juga berpotensi melestarikan kesuburan tanah. Daun yang lebar mampu meningkatkan karbohidrat lebih banyak melalui fotosintesis yang menunjang pertumbuhan dan hasil berupa bobot biji per tanaman dan berat biji per hektar, berat 100 biji (kacang tanah), berat kering berangkasan dan indeks panen.

Hal ini menunjukkan residu pupuk kandang sapi $30 \mathrm{t} / \mathrm{ha}$ sudah optimum dapat menunjang pertumbuhan dan hasil kacang tanah. Walaupun demikian masih ada kemungkinan untuk meningkatkan takaran pupuk kandang sapi dalam budidaya tanaman secara tumpangsari. Pertumbuhan vegetatif tanaman membutuhkan jumlah nitrogen yang besar. Laju pertumbuhan tanam yang meningkat diakibatkan oleh adanya pupuk nitrogen atau dari tanaman legum seperti kacang tanah yang dapat menambat $\mathrm{N}$ dari udara dan menyediakannya di dalam tanah untuk kebutuhan tanaman yang ditumpangsarikan dengannya. Menurut Sasa (2012), semakin besar sumbangan hara dalam tanah maka pertumbuhan tanaman akan semakin meningkat sampai pada batas tertentu. Menurut Kamil (1997), peningkatan berat biji pada tanaman tergantung pada tersedianya asimilat dan kemampuan tanaman itu untuk mentranslokasikannya pada biji.

Hasil penelitian menunjukkan bahwa jarak tanam tidak berpengaruh nyata pada semua parameter lingkungan (suhu, Kadar lengas tanah) yang menurun dengan baik pada petak bekas penanaman pertama. Pada jarak tanam yang lebih rapat $(20 \mathrm{~cm} \times 70 \mathrm{~cm})$ menunjang hasil biji tanaman kacang tanah paling baik. Hal ini mempengaruhi efisiensi pemakaian cahaya matahari, air dan unsur hara yang dipakai dengan baik sehingga tidak jatuh ditempat tanpa populasi tanaman. Menurut Hidayat dan Purboyo (1984), jarak tanam dapat mempengaruhi populasi tanaman karena makin renggang jarak tanam yang digunakan maka populasi tanaman makin kurang dan sebaliknya makin rapat jarak tanam maka populasi tanaman per satuan luas makin banyak. Supriyatman (2011) menyatakan bahwa lebar tajuk antara tanaman yang ditumpangsarikan akan berpengaruh terhadap penerimaan cahaya matahari, lebih lanjut akan mempengaruhi hasil sintesa dan muara terakhir akan berpengaruh terhadap hasil secara keseluruhan. Menurut Harjadi (1991), penggunaan jarak tanam yang ideal bagi tanaman akan memperkecil terjadinya kompetisi bagi tanaman, sehingga dapat memberikan hasil yang optimal.

\section{Simpulan}

Berdasarkan hasil penelitian ini menunjukkan bahwa tidak terjadi interaksi antara residu pupuk kandang sapi dengan jarak tanam pada semua parameter pengamatan. Perlakuan residu pupuk kandang sapi menunjukkan berbeda nyata dengan kontrol pada semua parameter pertumbuhan maupun parameter hasil dengan hasil biji kering per hektar diberikan oleh residu pupuk kandang sapi 30 t/ha. Perlakuan jarak tanam menunjukkan bahwa tidak berbeda nyata pada semua aras perlakuan kecuali pada parameter berat biji pertanaman, jarak tanam $20 \mathrm{~cm}$ x $70 \mathrm{~cm}$ menghasilkan biji kacang terberat.
Pustaka

Adiku, S.G.K., S. Narh, J.W. Jones, K.B. Laryea, G.N. Dawuona. 2008. Shortterm effects of crop rotation, residue management, and soil water on carbon mineralization in a tropical cropping system. Plant and Soil 311:29-38.

Baherta. 2009. Respon Bibit Kopi Arabika Pada Beberapa Takaran Pupuk Kandang Kotoran Ayam. Jurnal Ilmiah Tambua, 8 (1) :467-472.

Blair, N., R.D Faulkner, A.R Till, G.J Crocker. 2006. Longterm management impacts on soil $C, N$, and physical fertility part III: Tamworth crop rotation experiment. Soil Tillage Res. 20:48-56.

BOA. 2008. Pertanian Organik Penyelamat Ibu Pertiwi. Denpasar. Bali Organic Association

Direktorat Budidaya Serealia. 2013. Kebijakan Direktorat Jenderal Tanaman Pangan dalam Pengembangan Komoditas Jagung, Sorgum dan Gandum. Direktorat Jenderal Tanaman Pangan. Kementan RI. Jakarta.

Gomez, K. A., Gomez, A. A. 2010. Prosedur Statistik Untuk Penelitian Pertanian. Edisi ke 2. UI Press: Jakarta.

Harjadi, S.S. 1991. Pengantar Agronomi. Gramedia. Jakarta.

Hakim, N; M. Y. Nyakpa; A. M. Lubis; S. G. Nugroho; M. A. Diha; G.B Hong; dan H. H. Bailey. 1986. Dasar-dasar Ilmu Tanah. Universitas Lampung. Lampung.

Hardjowigeno, S. 1987. Ilmu Tanah. Ilmu Tanah. PT. Medyatama Perkasa. 216. hlm.

Hidayat, O. O. dan I. Purboyo. 1984. Groundnut Production, Utilization and Further Research Needs In Indonesia. Indonesian Agriculture Research and Development Journal 6 (3 and 4). The Ministery of Agriculture Agency For Agriculture Research and Development. Jakarta

Kamil. 1997. Teknologi Benih. Angkasa Raya. Padang.

Ikun, 2019. Pengaruh Takaran Pupuk Kandang Sapi Dan Pengaturan Jarak Tanam Terhadap Pertumbuhan dan Hasil Sorgum (Sorgum Bicolor L.) dan Kacang Tanah (Arachis Hypogeae L.) dalam Tumpangsari. Universitas Timor.

Lihtourgidis A.S., C.A. Dorgas, C.A. Damalas, D.N. Vlachostergios. 2011 Annual Intercrops: an alternative pathway for sustainable agriculture. Review Article. Australian Journal of Crop Science 5(4): 396- 410.

Mayadewi, N.N.A. 2007. Pengeruh Jenis Pupuk Dan Jarak Tanam Terhadap Pertumbuhan Gulma Dan Hasil Jagung Manis. Agritrop. 26 (4): 153-159.

Murrinie, E. D. 2010. Analisis Pertumbuhan Tanaman Kacang Tanah dan Pergeseran Komposisi Gulma pada Frekuensi Penyiangandan Jarak Tanam yang Berbeda. Tesis. Universitas Gadjah Mada. Yogyakarta.

Mohammad, W., S.M. Shah, S. Shehzadi, S.A. Shah. 2012. Effect of tillage, Rotation, And Crop Residues On Wheat Crop Productivity, Fertilizer Nitrogen And Water Use Efficiency And Soil Organic Carbon Status In Dry Area (rainfed) of North-West Pakistan. J. Soil Sci. Plant Nutr. 12:715-727.

Novizan. 2007. Petunjuk Pemupukan yang Efektif. Agromedia Pustaka. Jakarta.

Permadi, 2005. Pengaruh Pupuk N, P dan K Terhadap Pertumbuhan dan Hasil Jagung hibrida dan Komposit di Lahan Kering. Jurnal Agrivigor 5 (1) : $9-15$.

Pratama, M. S. 2014. Tumpangsari Tanaman Jagung Dan Kacang Tanah Terhadap Pertumbuhan Dan Hasil Jagung Dengan Penerapan Pupuk Urea. Skripsi. Fakultas Pertanian. Universitas Lampung. $94 \mathrm{hlm}$.

Sasa, F. S., 2012. Upaya Peningkatan Serapan Nitrogen Dan Produksi Sawi Melalui Aplikasi Pupuk Cair Organik Biomassa Tithonia. Skripsi Faperta Undana, Kupang.

Sarief, S., 1989. Fisika-Kimia Tanah Pertanian. Bandung: CV. Pustaka Buana.

Supriyatman, B. 2011. Introduksi Teknologi Tumpangsari Jagung dan Kacang Tanah. Karya Ilmiah.IPB. Bogor.

Suprijadi, Abdulrachman, S., Juliardi, I., Pahim. 2000. Pemupukan Berimbang pada Tanaman Padi di Lahan Sawah Irigasi dan Tadah Hujan. Prosiding Seminar Membangun Sistem Produksi Tanaman Pangan Berwawasan Lingkungan. Pati, 7 Nopember 2000. Pusat Penelitian dan Pengembangan Tanaman Pangan. Hal. 139-144.

Subowo G.2010. Strategi Efisiensi Penggunaan Bahan Organik untuk Kesuburan dan Produktivitas Tanah Melalui Pemberdayaan Sumberdaya Hayati Tanah. Jurnal Sumberdaya Lahan Vol. 4 No. 1, Juli 2010.

Vyan, 2009 manfaat dan kacang tanah jurnal imlia. Ha; 1-8

Yulia, A.E. dan Murniati. 2010. Aplikasi Pupuk Organik Pada Tanaman Caisim untuk Dua Kali Penanaman. Jurnal Teknobiologi 1(2): 19 - 26.

Yulia, A.E., Murniati, Fatimah. 2011. Aplikasi Pupuk Organik Pada Tanaman Caisim untuk Dua Kali Penanaman. Sagu 10:14-19 